\title{
Plánování čistých měst
}

\section{Planning Purified Cities}

\author{
Richard Sennet†
}

\begin{abstract}
Sennett's early book The Uses of Disorder (1970) emphasizes the way the increasing complexity and excessive order in modern society interrelates with the decrease of the complexity of its social forms. This is - among others - expressed in the loss of personal attitudes of the citizens and of their possibility to establish functioning communities. In the fourth chapter, "Planning Purified Cities", Sennett supports this thesis within the example of the power relations incorporated in the process of urban planning. He locates the origin of the modern urban discourse in the reconstruction of the city of Paris directed by Baron Haussmann at the end of the nineteenth century as an articulation of the needs of the developing industrial world. The main assumptions of this urban tradition are: centralized planning of the entire city, and predetermined social use of the city. Sennett points to the historical determinacy of these assumptions leading to the dominance of the expert knowledge above the needs of the actual inhabitants. In this tradition, the authority results into passivity and non-participation, eliminating the distracting elements: mistakes, anarchy, diversity or creative disorder. As well as in the other parts of his book, Sennett arrives at the critic of an immature and adolescent society whose members are not able to actively and non-violently deal with the challenges of life.
\end{abstract}

KEY WORDS communal life, metropolitan-regional planning, modern society, purity, technological development, urban planning

Dosud prozkoumávaný terén nám odhaluje nového člověka žijícího v novém společenství: sekularizovaného puritána, obávajícího se své vlastní schopnosti objevovat něco, co nemůže mít předem pod kontrolou; život společenství, jehož instituce, přesněji řečeno rodina, podporují ono puritánství natolik, že se z něj stává trvalý životní styl. Tato nová odrůda puritána dokázala neustále zjednodušovat a zprimitivňovat sociální rámec lidské existence. Přesto se brutalita podnětů, jež vyvolával, vyjevila právě uprostřed velkého rozkvětu technologie a mechanických objevů.

Ke vzrůstu technologické komplexity moderní společnosti a k poklesu komplexity jejích sociálních forem nedocházelo zcela nezávisle. Dopad technologických procesů na život společenství se projevil především v oblasti, která se na první pohled mưže zdát odtažitá. Touto sférou je skupina předpokladů, jejichž prostřednictvím profesionální projektanti přemýšlejí o městech a následně je utvářejí. K tomu, abychom v rámci společenství lépe využili technologie produkující nadbytek, je bezpochyby potřeba obrátit některé technologické předpoklady týkající se výstavby rozsáhlých velkoměst. Tyto předpoklady poprvé vstoupily na scénu

Sociální studia. Fakulta sociálních studií Masarykovy univerzity, 2/2006. S. 87-96. ISSN 1214-813X.

Překlad je převzat z: Sennett, Richard: „Planning Purified Cities“, in: The Uses of Disorder. Personal Identity and City Life, Faber and Faber: London 1996, s. 85-103 (původní vydání Alfred A. Knopf: New York, 1970). 
před sto lety v Paříži a jsou nyní rozšířeny naprríč většinou západní Evropy a Spojených států. Století budování velkoměst zaměnilo, slovy Lewise Mumforda, společnost využívající stroje za vizi samotné společnosti jako stroje. Jsem přesvědčen, že dokud zůstane zachováno spojení svérázného kalkulu efektivity ř́dícího převažující část městského plánování s novou koncepcí využívání měst lidmi, budou projektanti vytvářet takové podmínky života ve městě, jež zesílí sklony ke sterilitě, a budou tak propagovat dobrovolnou rezignaci na sociální participaci a ochotu využít násilí jako konečné řešení.

Dovolte, abych hned v úvodu vyjasnil, že nežádám, abychom zavrhli současný technologický př́stup ve prospěch protikladu v podobě „lidských hodnot“, nebot’ nástroje jsou samy lidskými výtvory a nikoli nepřátelskou nezávislou entitou. Velmi politováníhodné je dnes navíc to, že kritici současných předpokladů plánování se inspirují pouze sto let starou vizí Camilla Sittea; soudobí kritici stále sní jeho sen o návratu k nějakému arkadickému, preindustriálnímu řádu, $v$ němž je potlačena dělba práce. Odkaz na problémy a nepružnost $\mathrm{v}$ oblasti technologie sloužil až př́iliš často jako argument pro záměrnou jednoduchost městského života - jakoby lidé mohli vytěsnit z mysli svou schopnost tvořit. Spolu s Lewisem Mumfordem věřím, že je nutné naučit se používat nástroje lidským způsobem, nikoli je, ve snaze zůstat lidmi, zavrhnout. Naším úkolem je nalézt správné sociální uplatnění pro rozsáhlé pokroky v oblasti výstavby měst, strojírenství, bydlení, hygieny a budování dopravní infrastruktury, $\mathrm{k}$ nimž došlo během minulého století.

\section{Sen barona Haussmanna}

Plánování měst odborníky je $\mathrm{v}$ dějinách měst nedávnou událostí. Důvodem je zde do značné míry to, že až do doby vzniku rozsáhlých průmyslových velkoměst nebyla městská společnost považována za zvláštní typ sociálního uspořádání. Dř́ivější sociální teoretici zaznamenali v různých ohledech množství rozdílů mezi venkovem a městem. Avšak ani v př́ípadě renesančních měst autoři jako Machiavelli neveřili, že by městská společnost byla podřízena odlišným pravidlům a že by byla založena na zásadně odlišném souboru nebo uspořádání sociálních zásad. Např́klad jedinečné osvobození většiny obyvatel preindustriálních měst od nevolnictví nebylo považováno za relevantní pro obecnou povahu „společenské svobody“. Městu nebyla přiznána důležitost takovéto výjimečné povahy; namísto toho bylo nahlíženo jako zlomek většího projektu. K vůdčím postavám městské společnosti proto nepatřili výjimeční představitelé konkrétních měst; byli jimi spíše papeži jako Sixtus V. nebo monarchové jako Ludvík XIV., který budoval poslední imperiální velkoměsta (nebot' Versailles bylo zcela jistě takovýmto místem, nikoli anti-městem, jak ho někteří nazvali).

Avšak ekonomický řád, který začínal splývat s městským životem zhruba před sto padesáti lety, proměnil pojetí měst rozvíjené sociálními mysliteli. Došlo $\mathrm{k}$ tomu, že města ztratila svůj dřívější tvar a lidé se tak začali pozastavovat nad tím, co jim bylo dříve důvěrně známé. Zaprvé technologické procesy a procesy hromadění kapitálu nebyly v industriální metropoli podřizeny onomu typu mocenské kontroly, který organizoval města v minulosti; původ těchto procesů leží mimo starší regulativní pravidla měst nebo městských států. Bylo by bývalo nesmyslné, aby vláda jednoho města sama upřednostnila železnici před lodní dopravou jako prostředek obchodování daného města: vyváženost obchodu už nemohla být kontrolována 
takto místně. Proces průmyslového utváření kapitálu se v tomto ohledu lišil od procesu utváření kapitálu podníceného obchodními a objevitelskými výpravami, jakými byly cesty za renesance sponzorované městy typu Benátek. Ideologické přesvědčení osobností z generace Johna Stuarta Milla zde opět hlásalo, že tyto nové průmyslové síly budou samy od sebe fungovat k prospěchu celého lidstva, nebude-li jim bráněno v činnosti jinými politickými (nebo emocionálními či historickými) okolnostmi.

Proto s tím, jak rostly populace a ekonomický význam průmyslových měst, stávala se města méně kontrolovatelnými a zásady sociální péče ztratily svou dějinnou sílu. Nyní už víme o odvrácené straně této transformace - o vysoké míře chudoby, nepředvídatelnosti zdravotního stavu a pracovního uplatnění, o nekonečně nudném fyzickém vzhledu oněch měst; stejně jako o ní věděly jasnozřivější osobnosti devatenáctého století. Právě jedné z těchto osobností, baronu Haussmannovi, vděčíme za podnět vedoucí k městské reformě, jež zaujala dominantní místo v naší vlastní éře.

Haussmann byl muž skromného původu, ale velkých myšlenek, který řídil, pod záštitou Napoleona III., rekonstrukci centra Paříže v 60. letech 19. století. Paříž byla v této době mozaikou industriálního a preindustriálního řádu. Na periferii i v některých centrálních oblastech rychle rostly nové továrny; avšak změt' křivolakých uliček a rozpadajících se budov byla stále centrem starých i nových ekonomických aktivit města, jehož obyvatelé se stávali pro představitele městské administrativy a sociálních služeb ve vzrůstající míré neznámými. Samotný pohyb po městě byl velmi obtížný - v roce 1840 zabrala chůze $\mathrm{z}$ jedné části Pařǐže do druhé hodinu a půl; tato vzdálenost může být dnes pěšky zvládnuta za třicet minut. Pro politické představitele byla obzvlášt’ děsivá skutečnost, že neexistoval způsob kontroly dělníků $\mathrm{v}$ př́ípadě občanských nepokojů, nebot' klikatící se ulice byly ideální pro vztyčení improvizovaných barikád.

Způsoby, jimiž Haussmann napravil chátrající bydlení, svízelnou dopravu, chybějící politickou kontrolu, jsou po nás důležité, nebot' on byl prvním, kdo nahlížel na řešení těchto problémů $\mathrm{v}$ jejich nevyhnutelné souvislosti. Způsoby řízení dopravy se zároveň mohly stát způsoby nakládání s obyvatelstvem v prrípadě propuknutí občanských nepokojů; způsob odstranění chátrajících obytných domů byl, podle Haussmannova přssvědčení, také způsobem vymezení vztahů mezi sociálními trrídami.

Haussmann začal propletence uliček protínat velkými, dlouhými, nesmlouvavě rovnými tř́dami, tř́́dami, jež mohly pojmout neuvěřitelné množství dopravy, sloužit jednoduchým způsobem $\mathrm{k}$ přesunu vojsk do bouřících se částí města a působit jako říční břehy oddělující odlišné socioekonomické městské části. Tyto široké třídy byly usouvztažněny s městskými institucemi podél linií poprvé vyznačených v průběhu baroka, ve významné éře městského plánování $\mathrm{v}$ šestnáctém a raném sedmnáctém století. Spojovaly vždy veřejný památník $\mathrm{s}$ veřejným památníkem; nikoli jednu skupinu lidí s jinou, čili entity, které by mohly rozvíjet vzájemné sociální vztahy. Pařížská dělnická čtvrt’ tak zůstala následkem Haussmannových reforem oddělená od nových průmyslových center na periferiích města. Tyto nové ulice tak opět často posloužily k zapuzení myšlenky na čistě sociální problémy chudoby a deprivace nižší střední tř́ídy, jež se tak ocitly mimo běžný pohled, skryty za velkolepými oslnivými bulváry.

Baron Haussmann byl bezpochyby velkým tvůrcem a nelze nevzít na vědomí pozitivní aspekty jeho činnosti. Avšak jeho odkaz našim současným městům, at' už zamýšlený či nikoli, tvoří hrozivě jednoduchá skupina předpokladů. 
Prvním z nich je, že je žádoucí nakládat s problémy města jako s celkem: tato domněnka poněkud bezmyšlenkovitě předpokládá, že protože existuje souvislost mezi fungováním sociálních, ekonomických a materiálních fenoménů města, je správné pokoušet se s nimi nakládat koherentním způsobem, takže změny jedné oblasti nevyhnutelně promění ostatní oblasti městského života předem určeným směrem.

Druhým předpokladem je, že je správné plánovat fyzický prostor pro předem dané sociální využití; tedy namísto předpokladu, že k tomu, aby došlo ke změně fyzického vzhledu města, by nejprve mělo dojít ke změně v jeho sociální struktuře, nám Haussmann odkázal domněnku, že má-li se proměnit sociální struktura metropole, je jaksi lepší a zcela jistě snazší změnit její fyzickou krajinu.

Tyto myšlenky se dnes zdají být natolik rutinní, že působí jako zcela zjevné obecné pravdy. Přesto nejde o nevyhnutelná pravidla, nýbrž ve skutečnosti o důsledek svébytné dějinné odpovědi, jíž lidstvo reagovalo na svou vlastní schopnost žít se stroji a technologickými artefakty, na nichž je postaven moderní byrokratický řád, at' už kapitalistický či socialistický. Tato svébytná dějinná odpověd’ může být nejlépe pochopena, zaměříme-li se na proměny - či lépe na zintenzivnění - Haussmanových domněnek v největším projektantském hnutí tohoto století, v hnutí metropolitně-regionálního plánování.

\section{Velké plány}

Na počátku druhé světové války se jedinci zabývající se uspořádáním velkoměst stali v podstatě zvláštním typem ideologů. Za jejich dogmatem se pravděpodobně neskrývaly emoce, nejednalo se ani o ideál velké intelektuální hloubky, nedostatek emocí a intelektu byl však více než vyvážen bezmeznou oddaností tomu, co začalo být nazýváno „metropolitním plánováním“. Tento ideál plánování, jenž nabral na síle ve 30 . letech 20 . století - ačkoli jeho zárodek byl obsažen v díle Ebenezera Howarda z přelomu století - navrhoval dovést předpoklady stojící za Haussmannovou rekonstrukcí Paříže o krok dál: městští projektanti by měli navrhovat sjednocené plány na rozvoj celých městských oblastí, koordinovat materiální, ekonomické a sociální úsilí nikoli pouze prostřednictvím soudní pravomoci jednoho města, ale také ve vztahu k potřebám ostatních měst v jeho okolí. Co bylo v Haussmannově díle předpokladem žádoucí schopnosti jedné části městského komplexu ovlivnit jiné části, se v ideologii metropolitního plánování stalo ideálem plánování částí z povahy celku.

To je samožrejmě jedna $z$ důvěrně známých moderních představ jednoty: základ určující podobu strojů a definující příznačně moderní pojetí „efektivity“ technologické a sociální organizace. Avšak, jak se úporně snažili dokázat historici typu Johna Nefa, tato představa je domněnkou o efektivitě, spiše než povahou efektivity samé. V preindustriálních továrních systémech byl průběh tvorby výrobku důležitější než typická představa, jasný obraz „,elku“; tehdejší řemeslníci tak předpokládali, že definujeme-li předem, jak by věc měla vypadat, narušíme její ,efektivitu“ neboli svobodu řemeslníka využít a vytěžit materiály a formy v průběhu výroby. V situaci průmyslové výroby je vytvářený produkt naplánován dopředu, takže jeho realizace, dosažení celku, je pasivní rutinou, nikoli aktivní zkušeností či procesem objevování. Předvídání výsledků práce před jejím samotným uskutečněním tedy umožňuje naplánovat 
výrobní proces tak, že „části jsou podřízeny celku“, nebot’ o jednotlivých složkách výroby se předpokládá, že neexistují samy o sobě, že nemají jinou roli než harmonicky pracovat směrem $\mathrm{k}$ vytvoření předem naplánované entity.

Tato výrobní mentalita zjevně akceptuje, či dokonce vítá nahrazení lidské práce automatizovanými nástroji. Navíc za pomoci této myšlenky se jedním z největších technologických úspěchů člověka $v$ posledních třech desetiletích stala automatizace takových výrobních prostředků, jako je montážní linka, u níž lidé vykonávali práci, jež neodpovídala jejich schopnosti být otevřen všemu novému a mnohotvárnému. Když se navíc tato výrobní mentalita, tento obraz strojové efektivity, přenese na vytváření měst, na navrhování sociálních částí z předem určeného, předem vizualizovaného městského celku, stane se výsledek nelidským.

Během plánování probíhajícího podél této linie projektant nejprve stanoví současné a budoucí „projektivní potřeby“ městské oblasti, a poté přejde k návrhu materiálního a sociálního vybavení oněch „částí“ sloužícího určeným potřebám. Předpokladem je, že čím větší je měřítko tohoto procesu, tím efektivnější, míněno automatičtější, jsou jeho výsledky. V nedávném, široce vyzdvihovaném souboru esejů o plánování editor dochází např́íklad k závěru, že:

...rozsah oblastí pokrytých plány by měl být průběžně zvětšován. Existuje určitá potřeba národního urbanizačního vzorce či strategie územního plánování pro celé Spojené státy; ty by navíc měly být na kontinentální úrovni sjednoceny s Kanadou a Mexikem. ${ }^{1}$

Stejný autor se domnívá, že pokud by měla takováto rozsáhlá koordinace uspět, bylo by nezbytné předem naplánovat všechny aspekty sociálního a ekonomického života v jejich vzájemných vztazích. Tento „sjednocený př́istup“ implikuje následující:

Estetické a humanistické hodnoty a instituce musí být $\mathrm{v}$ plánovaném vztahu $\mathrm{k}$ ekonomickým a politickým hodnotám a institucím. Všechny tyto činnosti tak musí tvořit jednotu, jak z materiálního hlediska, tak jako sociální struktury. Musí jednoduše dojít k provázání veřejných a soukromých struktur. ${ }^{2}$

Nejde o prohlášení šíleného supermana. Jde spíše o jasné vyjádření cílů široké a vlivné části profesní skupiny, jež plánuje moderní města. Jejím ideálem je mít vše pod kontrolou. Abychom mohli životu takto přitáhnout otěže, musí být nejrůznější typy aktivit převedeny na své nejnižší společné jmenovatele. Výsledkem projektantského úsilí vedeného podél těchto linií je to, že se budoucí prostředí stane funkcí projektantovy vize př́tomnosti, tak jako je stroj produktem svého konstruktéra a nikoli továrního výrobce. Obyvatelé budoucích městských prostor tak nemají možnost přizpůsobit je svým představám, jako si např́klad př́slušníci židovských ghett ve střední Evropě postupně přizpůsobili prostředí čtvrtí, do nichž se nastěhovali. Tento historický proces je nahrazen arbitrárním ustanovením o tom, kdo je kde způsobilý bydlet.

Jinde jsem ukázal, jak mohla metoda „projektovaných potřeb“ sloužit coby trik umožňující vyhnout se v budoucnosti neznámému. V současnosti je na tomto prrístupu obzvlášt' mechanické to, jak většina projektantů následujících tuto linii uvažuje o „potřebách“ městských obyvatel nikoli na základě poznané zkušenosti, ale spíše z hlediska umístění městského

$1 \quad$ W. Wentworth Elridge (ed.) 1967. Taming Megalopolis. Garden City, NY: Anchor Books, s. 1158.

2 Tamtéž. 
člověka do řádu, v němž jsou potřeby vnímány abstraktně, jako součásti celkové funkce. $\mathrm{Na}$ námitky osob vymístěných vysokopodlažními budovami či městskými revitalizačními projekty projektanti odpovídají, že pracují z ohledem na celek města; daný metropolitní region je ale „komunitou“ pouze v míře, v níž lze za „komunitu“ označit fungující součástky stroje.

Haussmannova první zásada, že změny $\mathrm{v}$ jedné oblasti městské činnosti by měly proměnit jiné sféry činnosti, se tímto transformuje $\mathrm{v}$ koncept, podle kterého se samo fungování města do značné míry odvozuje z propojení jeho specifických aktivit. Nerozhoduje, co lidé dělají nebo prožívají ve svých vlastních životech, nebot' je to vnější vztah tohoto jednání k oblastem nepř́mé zkušenosti, co tvoři střed zájmu. Nikdo se dnes nemůže s metropolitními plánovači přít o to, že tyto vnější vztahy, tyto průsečíky, existují a že utvářejí určité významné typy vztahů v rámci města. Otázkou je, proč je přijímat jako důležitý střed zájmu? Proč zdůrazňovat skutečnost jejich existence jako žádoucí hodnotu? To, že je dosažení nejvyšší efektivity fungování celku nejlepším způsobem uplatnění jeho částí, platí pro konstrukci strojů, avšak jak lze tento př́stup obhájit ve vztahu k lidské činnosti? Naopak člověk by měl být odhodlán vybočit $\mathrm{z}$ cesty nejmenšího odporu ve vzájemném jednání, odhodlán vytvářet vztahy lišící se svým uspořádáním a směřováním od těch, jež měl dosud možnost poznat: tímto způsobem ho fenomén dějin odlišuje od jiných zvířecích druhů.

\section{„Městský celek“ jako Mýtus čistoty}

Fakt, že progresivní pojetí městského plánování zaujala tento tón, souvisí s tím, jak se projektanti staví k možné komplexitě městského života. Vedl je popud dát průchod specifické lidské tendenci - vyvinuté během dospívání - ovládnout neznámé hrozby vyloučením pravděpodobnosti překvapivého zážitku. Tím, že člověk ovládne rámec možných sociálních interakcí, podřídí si následný průběh událostí. Sociální dějiny jsou nahrazeny pasivním „výtvorem“ sociálního plánování. Pod onou touhou po plánování podél automatizovaných linií je skryta snaha vyhnout se bolesti, snaha stvořit transcendentální životní rád, jenž bude imunní vůči různorodosti a stejně tak vůči nevyhnutelnému mezilidskému konfliktu. Pojd’me nahlédnout na príčiny tohoto stavu.

Metafora metropolitního plánování je odrazem technologie, s jejíž pomocí jsou vytvářeny moderní stroje. Strojové součástky se od sebe bezpochyby liší, avšak existence těchto rozdílů slouží k naplnění shodné funkce: jakýkoli konflikt mezi součástkami, či dokonce existence součástek pracujících nezávisle na celku by mohly ohrozit účel stroje. Stroj nepočítá $\mathrm{s}$ př́tomností bolesti či chyby.

Je-li však tato technologická metafora užita na strukturu městské společnosti, její významy se proměňují. Technologická metafora městského růstu zde přebíjí potřeby, kvůli kterým existuje celek, protože tyto potřeby jsou zakotveny v lidských bytostech jako částech sociálního celku, ne v nějakém společenském produktu mimo sociální zkušenost. V plánování měst podle strojového modelu se urbanisté snaží „sjednotit“ tyto potřeby transcendentálním způsobem a pro účely takovéhoto sjednocení jsou konflikt a bolest v rámci součástí lidského města nahlíženy jako něco negativního, jako vlastnosti, jichž je třeba se zbavit. Jde zde o stejný postoj, jaký nacházíme $\mathrm{v}$ nepřiměřené porevoluční disciplíně či v úniku hledajícím útočiště na čistém předměstí. Vlastní, bezprostřední lidská zkušenost v celé její dosažitelné 
svobodě a mnohotvárnosti je považována za méně důležitou než stvoření společenství zbaveného konfliktů; smysl života v př́tomnosti je znesvěcen kvůli ideální společnosti, v níž lidé žijí v takové harmonii, že není možné si je nikdy představit vyrůstat způsoby, jež by znesvětily „správné“" vztahy, které mezi sebou mají.

Technicistní pojetí metropolitního plánování tak vede ke vzniku adolescentní společnosti stejně snadno, jako tak činí malá izolovaná předměstí. Je výjimečné, aby městské plánování pod touto maskou alespoň zvážilo, tím méně podpořilo, rozvoj sociálních institucí, jež by mohly v daném společenství vyvolat napětí v důsledku podpory rozdílů mezi lidmi. Konflikt je považován za hrozbu namířenou proti nějakému „lepšímu“, bezkonfliktnímu způsobu městského života. A dojde-li ve městě ke konfliktu, neexistuje mezi profesionálními projektanty dokonce žádná představa, jak by se mohl rozvíjet, aniž by vedl k násilí. Protože východiska metropolitního plánování jsou tak naivní ve svém pojetí správného města, protože jsou výrazem adolescentního vzdoru zabývat se světem v celé jeho složitosti a bolesti, musí prohloubení městského konfliktu nutně vyústit $\mathrm{v}$ násilí; nebot' projektanti se ve skutečnosti nezabývají zprostředkováním skutečného lidského chování nebo vytvářením prostor bez jasně vymezených vztahů. Esencí mechanismu očisty je strach ze ztráty kontroly. Skutečné nepokoje jsou problémem, jenž je podle mínění projektantů nejlepší přenechat politikům a jim podobným. Namísto toho se pohledy projektantů upírají na městský „,celek“; projektanti sní o úžasném městě existujícím kdesi mimo přítomnost, úžasném městě, kde spolu lidé jednají v míru a harmonii, o městě ve skutečnosti tak úžasném, že obyvatelé ghett, irští policajti, aristokratičtí WASPové, hippies, studenti, kněží a účetní přivřou oči nad tím, co na sobě nesnášejí, nad bolestnou skutečností vzájemných rozdílů, a začnou žít životem št’astného společenství.

Existuje skrytý rozměr tohoto metropolitního ideálu. Ve společenstvích uspořádaných na základě jednoty, které sledoval Tocqueville, mělo vytvoření obecného obrazu solidarity zbavit členy společenství potřeby konfrontace a rozvíjení bezprostředních vzájemných vztahů. V idealizaci jednoty prosazované profesionálními městskými projektanty se objevuje podobná rezignace. $\mathrm{Z}$ pohledu rozhodování o záležitostech města však vede takováto rezignace k selhání efektivity, k neschopnosti dosáhnout toho, o co sami projektanti usilovali. Tuto neschopnost zapř́ičiňuje samotná podstata technicistní metafory př́itomné v holistickém plánování. Stroje totiž nemění své výstupy na základě spontánních proměn svých součástek, s výjimkou toho, že se rozbijí. Když se součástky stroje opotřebují, což je jejich „forma zkušenosti“" v čase, činnost stroje se zastaví. Avšak esencí lidského vývoje je prítomnost rưstu v momentě, kdy selžou staré rutinní postupy, poté, co už staré součásti nevyhovují potřebám nového organismu. Stejný typ změny, v širším ohledu, dává vzniknout v rámci určité kultury fenoménu dějin.

Vyjádřeno konkrétněji: dnešní plány či „,vzorové šablony“ jsou utvářeny pro celé metropolitní regiony. Projektanti se snaží rídit budoucí dějiny svých měst podle předem určených, vymezených linií; některé části plánu v momentě jeho realizace historicky směřují ke konfliktu s jinými částmi; o takovémto plánu se posléze předpokládá, že selhal. „Celek“ se rozpadl, nebot' se neuvažuje o tom, že by byl schopen se vyvíjet nepředvídaným způsobem. Růst, v plánování obrovských měřítek, je namísto toho pojímán automaticky jako realizace původní vize. Toto byl vnitřní rozpor, který ochromil samotnou podstatu plánování rozsáhlých velkoměst; neexistuje zde návod, jak zacházet s dějinami, s nezamýšleným, s protikladným, s neznámým. 
Ve své jasnozrrivé a neprávem opomíjené knize The Last Landscape (Poslední krajina) ukázal William H. Whyte nemohoucnost projektantů pracujících uvedeným způsobem při jejich pokusech o uspořádání Washingtonu, městského regionu. Projektanti zde uplatnili ideální obraz městského růstu tak, že reálná historie města nyní působí jako jeho znesvěcení; k novému rozvoji obytných a obchodních funkcí dochází v oblastech, v nichž projektanti růst neočekávali; centrální oblast města se obnovuje způsoby, jež nebyly původně předpokládané. Odpovědí projektantů, jak Whyte ukazuje, nebyla snaha pochopit nové změny a poučit se z nich, nýbrž spíše volání po zesílení policejního dohledu, jenž by dokázal vynutit původní představu. Selhání v zajištění podpory těchto sil vedlo k rezignované pasivitě původních projektantů: co mohou dělat, pokud nemohou mít situaci ,pod kontrolou“? Právě proto, že je ideál plánování v obřím měřítku ve svých východiscích odolný vůči myšlence historického vývoje městského života, jsou projektanti v důsledku vždy odsouzeni k tomu, aby se vzdali kontroly. Tímto způsobem došlo, zevnitř, k vytvoření vakua v profesionálním řizení měst.

Zřetelně, bolestně zřetelně se toto vakuum odrazilo na způsobu plánování dálnic ve velkých amerických a západoevropských městech. V tomto konkrétním př́ípadě nechyběly finanční zdroje a vládní podpora plánů, zajišt'ovaná prostřednictvím příslušných úradů pro správu silnic a dopravní infrastruktury; když už nic jiného, měly tyto programy v amerických městech téměr̆ tyranizující moc prosazovat své myšlenky. Přesto však selhaly, nikoli pro nedostatečnou technologickou odbornost, ale proto, že neměly sílu se v průběhu času přizpůsobit: nebyla vytvořena alternativní řešení vztahu dopravy a proměňujícího se charakteru samotného vnitřního města. Projektanti nepředvídali prostředí odlišné od toho, o němž uvažovali v jednotlivých ,etapách plánování“; avšak poté, co byly zbudovány silnice, rozhodlo se větší množství osob pro jízdu automobilem a došlo ke vzrůstu využití automobilové dopravy. Situace v dopravních zácpách tak zůstala stejně problematická jako před výstavbou nových dálnic, pouze se značně znásobilo její měřítko. Chyba není v tom, že by projektanti nedokázali být vševědoucí, nýbrž v tom, že se za vševědoucí pokládali předtím, než začali stavět, a nevytvořili proto žádná alternativní řešení umožňující v průběhu realizace dlouhodobých plánů velkého měřítka změnu a vývoj vlastních návrhů, nemluvě o uvažování nad tím, zda je vhodné pokračovat v původních návrzích.

Humanisté si často zoufají nad tím, co označují jako neporazitelnou moc technologických sil. Avšak technologické vzorce, stejně jako vše ostatní, co vyrůstá ze specifické dějinné situace, má moc přejímat kontrolu pouze nad silami, jež se týkají jejich vlastní expanze. A protože expanze strojní technologie nebyla zapříčiněna sociálními silami přímo svázanými s městskou strukturou, jejich uplatnění na oblast městského rozvoje je odsouzeno k selháním podobného druhu, jež nyní můžeme sledovat v oblasti dopravy, veřejného a veřejně rízeného stěhování a dalších. Při utváření měst se technicistní metafora neosvědčila; jednoduše nefunguje.

S ohledem na lidské ,,součástky“ zapojené do onoho procesu nás nyní přiměla díla takových urbanistů, jako jsou Charles Abrams, Jane Jacobs, Marc Fried a Herbert Gans, k bolestnému uvědomění si toho, kolik ze života skutečných lidí bylo zničeno pro účely realizace nějakých abstraktních rozvojových či revitalizačních plánů.

Například Fried ve své výtečné eseji „Grieving for a Lost Home“ (Zármutek nad ztraceným domovem) zdokumentoval pocity náhlé prázdnoty zažívané skupinou běžných obyvatel měst, již byli vystěhováni z upadající oblasti vyhrazené pro městskou revitalizaci do čistých, moderních a hotově navržených bytů rozptýlených po celém městě. Lidé, kteří si vytvořili 
sousedské vazby, každodenní vztahy přátelství a důvěry, si náhle připadali izolovaní a osamělí jako uprchlíci, a to v důsledku změny učiněné „pro jejich vlastní dobro“. Odpovědí projektantů na tento typ stížností bylo tvrzení, že každá sociální změna vyžaduje něčí přesídlení. Nepochybně; koho pak ovšem projektanti označí za konečné adresáty změn, jež navrhují? Zcela jistě ne obyvatele předměstí - to, o co tito lidé usilují a čeho se jim dostává, je odloučení od regionu jako celku; výsledky široké škály nedávných výzkumů mezi obyvateli nižší a nižší střední tř́́dy, jež byli přesunuti z oblastí svého starého bydliště do nových, předem rozvržených společenstev, opět odhalují stejný „zármutek“, který zaznamenal Fried. Tyto studie nezmiňují žádné bezbřehé nadšení na straně běžných obyvatel měst ve vztahu k jejich novému bydlišti, jež je součástí velkolepého plánu.

Nestačí, když městští projektanti tvrdí, že oni poskytují technologické podklady pro život ve společnosti a že odpovědnost za jejich využití spočívá na obyvatelích města. Toto tvrzení patří $\mathrm{k}$ těm, s nimiž začali sami zástupci prrírodních věd zacházet $\mathrm{s}$ velkou podezrŕvavostí. Soudobá vědecká komunita dospěla v posledních desetiletích $\mathrm{k}$ názoru, že nic, co bylo člověkem vynalezeno, nelze oddělit od využití lidmi; neexistuje lidsky „neutrální“ činnost tvoření či vynalézání, bez ohledu na to, jak velký odstup či objektivitu vědec ve vztahu ke svému dílu cítí. $Z$ toho si nyní musí vzít poučení i komunita projektantů: musí převzít odpovědnost za své jednání v historické, nepředvídatelné společnosti spiše než ve vysněném světě harmonie a předjednaného řádu.

Aby moderní města sloužila potřebám člověka, musíme změnit způsob práce městských projektantů. Namísto plánování nějakého abstraktního městského celku musí projektanti začít pracovat pro konkrétní městské části a pro odlišné sociální vrstvy, etnické a rasové skupiny, jež se v nich vyskytují. A práce, kterou pro tyto lidi učiní, nesmí opomíjet jejich budoucnost; lidé nebudou mít možnost dospět, pokud to nebudou sami chtít, pokud nebudou aktivně zapojeni do utváření podoby svého sociálního života. Ale protože životní potřeby nejsou beztvaré - a protože připisujeme význam růstu a nikoli bezcílnému putování -, mohou být projektanti zdrojem sociálního materiálu, jehož prostřednictvím se členové komunit budou moci sami zcivilizovat.

Tento názor je mnohem komplexnější, něž se může na první pohled zdát. Narozdíl od mnoha dělníků sdružených v komunitách, jež o sobě uvažují jako o Nové levici, nemohu přistoupit na to, že cokoli komunita sama udělá, je správné per se, nebot' to bylo takto institucionalizováno; lidé mohou chtít být společně krutí, jako němečtí nacisté či skupiny bělošských nuzáků, jež terorizovaly černochy na tehdejším americkém Jihu. Impuls k vytvoření obecného řádu represivní povahy vychází přirozeně z lidských životů. Avšak právě s ohledem na stejný komplex tužeb po sdílené mytické solidaritě se člověk nemůže stát jednoduše dobrým pouze následováním správného doporučení nebo přijetím dobrého plánu, jejichž autorem je někdo jiný. Mezi bezcílným blouděním veřejným životem a autoritářsky řízeným společenstvím vede střední cesta, jež není kompromisem mezi dvěma extrémy, nýbrž zcela novým př́stupem. Tento nový způsob městského plánování by mohl vytvořit podklady, jež lidské bytosti potřebují a jež se nachází mimo jejich vlastní svět, $\mathrm{k}$ tomu, aby vyrostli z oněch svérázných návyků osvojovaných v předvečer dospělosti učících je ustupovat před novými a neznámými zkušenostmi.

Přeložila Pavlína Binková 


\section{Autor}

Richard Sennett působí jako profesor sociologie na London School of Economics a na Massachusetts Institute of Technology. Je autorem četných textů, v nichž se věnuje především kritické reflexi městské kultury, veřejného života, urbánních dějin či systému moderního kapitalismu. Jeho nejnovější publikací je The Culture of the New Capitalism (Yale University Press, 2006), mezi starší vlivná díla mimo jiné patří The Uses of Disorder: Personal Identity \& City Life (1970), The Hidden Injuries of Class (spolu s Jonathanem Cobbem, 1972), The Fall Of Public Man (1974), The Conscience Of The Eye (1990), Flesh And Stone. The Body And The City In Western Civilisation (1994), The Corrosion Of Character. The Personal Consequences Of Work In the New Capitalism (1998), Respect in a World of Inequality (2003). Kontakt: r.sennett@1se.ac.uk 